\title{
UC LOUVAIN - LOCI. DE LA REALITĂTTILE ORAȘULUI LA ACTIVITǍT,I DE PREDARE ȘI CERCETARE
}

Asist. dr. arh. Anda-loana Sfinteș

anda.sfintes@uauim.ro

UCLOUVAIN - LOCI

SAINT-GILLES, BELGIA

$11 / 2018-12 / 2018$ 


\section{INTRODUCERE}

Bruxelles și zona sa metropolitană cu cele 19 comune formează deopotrivă o unitate (prin delimitări vagi sau chiar insesizabile) și o alăturare de entități cu caracteristici și mai ales identități proprii. Intervenții urbane majore făcute în secolele XIX și XX - de tăiere a unor mari bulevarde, de săpare a unor tuneluri care să faciliteze transportul feroviar - au contribuit la întărirea dezvoltării relativ unitare, la întărirea relațiilor în teritoriu și la transformarea Bruxellesului într-un oraș al mobilității crescute. La scară mai mică, numărul mare de ganguri, de pasaje pietonale și comerciale (la care se adaugă numărul mare de străzi pietonale), fac din oraș unul dintre cele mai deschise către traficul pietonal, fascinant de parcurs și descoperit prin astfel de scurtături ce schimbă major experiența pietonului față de cea a utilizatorului de transport în comun sau a șoferului. Gesturile urbane majore și statutul actual al orașului și zonei sale metropolitane lasă loc însă, după cum vom vedea într-o oarecare măsură în proiectele abordate la UC LouvainLOCI și nu numai, unor probleme de redescoperire a identității (Fig. 1), de reconstruire a legăturilor la scară urbană, unor probleme legate de posibilități actuale de densificare și intensificare sau de soluționare a unor provocări ecologice, sociale etc.

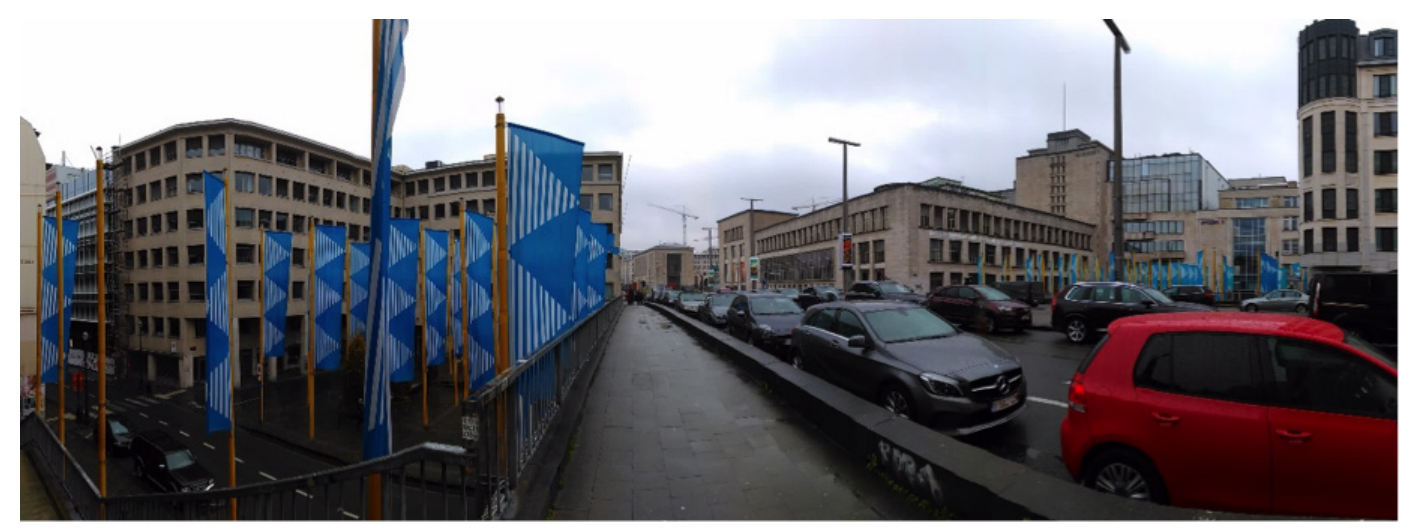

Fig. 1. Unul din siturile abordate - intersecția Boulevard de l'Empereur (deasupra) și Rue de l'Hôpital/ Rue Lebeau (dedesubt) - o zonă considerată a nu-și fi găsit încă identitatea.

Din punct de vedere al identității, se constată că fiecare regiune este caracterizată de alte structuri ale populației (din punct de vedere etnic, al statutului social), de alte nevoi, facilități, servicii în strânsă legătură cu structura populației (de exemplu, Anderlecht în special cartierul Cureghem - este recunoscută drept comuna imigranților nou-veniți, Saint-Gilles este unul din centrele artistice și studențești importante, Schaerbeek este una dintre cele mai populare și cosmopolite comune). 
Aceste realități au fost cel mai evident transpuse în cadrul unora dintre proiectele de atelier de nivel Master 1 și Master 2 urmărite pe parcursul stagiului de o lună desfășurat la UC Louvain-LOCI în perioada noiembrie-decembrie 2018. O observare proprie a siturilor analizate de către studenți a completat înțelegerea abordărilor și a ajutat la filtrarea informațiilor prin prisma posibilităților de raportare a metodelor la obiectivele didactice ale Universității de Arhitectură și Urbanism "Ion Mincu", București. Înțelegerea în profunzime a siturilor abordate, a metodelor adoptate în paralel cu realitățile orașului și zonei metropolitane a scos în evidență scopul întregului proces didactic și de cercetare, subliniind utilitatea rezultatelor prin raportare la nevoile orașului și locuitorilor, la practica profesională, la dezvoltarea capacității de inovare și la dezvoltarea autonomiei studenților. O mică parte din studenți au lucrat chiar pe terenuri din București iar abordările lor au evidențiat utilitatea unei depărtări afective de situri și problemele abordate ca exerciții de intervenție în căutarea sau regăsirea unei identități spațialtipologice în ciuda posibilităților reale de intervenție.

Stagiul s-a desfășurat până la predarea și jurizarea proiectului de atelier de semestrul 1, ceea ce a permis urmărirea aproape a întregului proces de cercetare și proiectare și raportarea acestuia la rezultate și critica finală.

Activitățile principale urmărite pe parcursul stagiului au fost cele de nivel Master 1 și Master 2, din cadrul atelierului cu tema Typology - voids și cele de la Séminaire de la recherche critique - Architecture, écrits (ambele îndrumate de prof. Christine Fontaine împreună cu alți colegi), dar și atelierele desfășurate în paralel. Alte cursuri și seminare urmărite au fost: Initiation à la recherche; Architecture, ville et territoire: théories et méthodes de l'urbanisme; Utopies et actualité de l'habiter, Moyens d'expression. În paralel am urmărit activitatea centrului de cercetare Metrolab.

\section{ACTIVITATE DIDACTICĂ - CONSIDERAȚII GENERALE}

La nivel de master programa este echilibrată, dincolo de cele $8 \mathrm{~h}$ pe săptămână de proiectare grupate într-o singură zi acoperind, prin diverse cursuri și seminare, domenii precum: 
(1) Expresie, reprezentare, comunicare,

(2) Metodologie și cercetare,

(3) Context și cultură,

(4) Materiale, structuri și construcție,

(5) Practică profesională.

Diversitatea materiilor studiate la nivel de master se poate observa în Tabelul 1.

Tabel 1. Conținutul planului de învățământ de semestrul 1, la nivel de master

\begin{tabular}{|c|c|}
\hline $\begin{array}{l}\text { Conținut plan } \\
\text { invătământ } \\
\text { master } 1 \text { sem. } 1\end{array}$ & $\begin{array}{l}\text { Questions d'architecture: 1. Histoire et théorie, 2. Patrimoine et mémoire, } 3 . \\
\text { Materialité et eco-conception } \\
\text { Architecture, ville et territoire: théories et méthodes de l'urbanisme } \\
\text { Initiation à la recherche } \\
\text { Equipements du bâtiment et flux } \\
\text { Construction, matériaux et équipements } \\
\text { Projet d'architecture } \\
\text { Aide á la recherche documentaire en bibliothèque }\end{array}$ \\
\hline $\begin{array}{l}\text { Conținut plan } \\
\text { invățământ } \\
\text { master } 2 \text { sem. } 1\end{array}$ & $\begin{array}{l}\text { Questions d'architecture: 1. Histoire et theorie, 2. Patrimoine et memoire, } 3 . \\
\text { Materialité et eco-conception } \\
\text { Gestion de projet et pratique professionnelle } \\
\text { Utopies et actualité de l'habiter } \\
\text { Droit et responsabilités professionnelles } \\
\text { Seminaire de la recherche critique: 1. Architecture, écrits, 2. Analyse des proces. } \\
\text { Du concept 3. Patrimoine hérité } \\
\text { Projet d'architecture } \\
\text { Aide à la recherche documentaire en bibliothèque }\end{array}$ \\
\hline
\end{tabular}

Din punct de vedere al desfășurării, este de menționat faptul că începutul lunii decembrie (ultima lună din semestru înainte de începerea sesiunii) marchează o ruptură la nivelul orarului: unele materii se desfășoară doar până la începutul acestei luni, în timp ce la multe dintre materiile care se continuă în această perioadă se desfășoară doar aplicații practice, exerciții îndrumate (ex. de cercetare, scriere academică).

Un alt element important observat este reprezentat de desfășurarea unora dintre ateliere și seminare în paralel cu studenții de Master nivel 1 și Master nivel 2. Totodată, la ateliere și seminare se participă de multe ori pe bază de opțiune, ceea ce oferă șansa studenților de a-și alege tipul de abordare sau de informații pe care doresc să le acumuleze. 


\section{ACTIVITATE DIDACTICĂ - METODE}

Urmărirea, în paralel, a metodelor didactice folosite în cadrul atelierelor, cursurilor și seminarelor la care am participat a condus la concluzia structurării acestor tipuri de activități în jurul unei gândiri matematice, de sinteză, raportată mereu la tipologii. în teme, prezentări și discuțiile cu studenții se urmărește constant plasarea atitudinilor în funcție de axe de analiză (într-o fază a variațiilor) și punerea în balanță a soluțiilor (selectate a fi cele mai ilustrative și duse mai departe în dezvoltarea de scenarii) astfel încât deciziile studenților cu privire la ilustrarea finală să fie asumate și argumentate.

Se urmărește mereu (încă din faza corecturilor) coerența prezentării grafice cu textul și prezentarea orală, justificarea proiectului, adresarea corectă a unor întrebări de cercetare (definirea scopului). Se pune accent pe găsirea și formularea temei de cercetare, precum și pe găsirea unui titlu adecvat, indiferent dacă este vorba despre proiecte de atelier sau despre lucrări de seminar. Aceste elemente devin prime forme de justificare a intervenției și atitudinii. Acest mod de lucru pare asumat de către studenți încă din anii mai mici de facultate, ceea ce facilitează procesul didactic și crește timpul alocat dezvoltării, dar și comentării soluției propriu-zise.

Nu în ultimul rând se pune accent pe elaborarea unei strategii în timp/posibilitatea implementării treptate, ceea ce vizează într-o mult mai mare măsură posibilitățile reale de intervenție, luând în calcul eșalonarea costurilor, dar și timpul necesar construirii publicului-țintă.

\section{ATELIER}

Tema de atelier de semestrul 1 ( temă comună pentru studenții de la Master nivel 1 și Master nivel 2) vizează elaborarea unui proiect conceptual și a fost propusă sub această formă cu scopul dezvoltării capacității studenților de a-și argumenta soluțiile.

Studenții optează pentru atelierul pe care doresc să îl urmeze având în vedere temele comunicate de către profesorii îndrumători. Temele-cadru acoperă o paletă largă de tipuri de abordări, de la intervenții punctuale, la intervenții la nivel urban sau chiar la rezolvarea de probleme urbanistice sau ecologice. În timpul stagiului, în cadrul celor trei ateliere care funcționau în paralel temele active erau: 
- $\quad$ typology. voids: investigarea spațiilor libere și propunerea de intervenții diferite tipologic; urmărirea implicațiilor acestor abordări tipologice la diferite scări

- $\quad$ heritage: propunerea de intervenții prin raportare la patrimoniu

- $\quad$ materiality: propunerea de intervenții ce au vizat problema reciclării și rolul arhitecturii într-un circuit al reciclării.

Scara intervențiilor variază în funcție de tema de cercetare stabilită de fiecare echipă de studenți în parte. Se lucrează în echipe mixte alcătuite dintr-un student de Master nivel 1 și un student de Master nivel 2. Astfel, studenții învață unii de la ceilalți, iar în cadrul corecturilor se diminuează nevoia oferirii de lămuriri privind demersul, tipul de abordare, conținutul planșelor, modul de reprezentare etc.

Analizele de început pornesc, în general, de la scară foarte mare (întregul sat/oraș), fiecare echipă de studenți decupându-și mai apoi propriul sit (care poate rămâne la scară mare - de exemplu un întreg bulevard cu toate insulele construite care îl bordează).

Numim câteva dintre problemele abordate de studenți în cadrul acestei teme:

- cum se poate (re)crea o legătură între o șosea/cale ferată și țesutul urban, legătură distrusă prin intervenția masivă a decupării șoselei/căii ferate într-un țesut existent;

- "habiter le train/le parc/le travail" » explorarea conceptului de locuire în contextul transformărilor ce caracterizează societatea actuală;

- intensitate vs. densificare;

- "espaces marchantes" - mobilitatea la nivel urban privită în contextul nevoii de mișcare/accesibilitate, dar și ca nevoie socio-economică sau motor al activității socio-culturale actuale;

- problema locuirii temporare cu accent pe gestiunea deșeurilor electrocasnice generate.

Metoda de lucru aplicată în cadrul atelierului urmărit (tema A) constă în:

- $\quad$ propunerea a 9 variații tipologice sub forma unor grafice ce urmăreau diferențierea pe două axe (ex. scara intervenției vs. adiție-substracție; permeabilitate vs. funcțiune; mobilitate vs. infrastructură etc.); aceste variații reprezintă atitudini ce pot fi replicate la scara întregului oraș, fapt pentru care contextul (altul decât cel de natură tipologică) este rareori luat în calcul în dezvoltarea acestor variații;

- $\quad$ dezvoltarea a trei scenarii selectate din cele 9 variații;

- $\quad$ propunerea unui studiu de caz, a unei viziuni ce ilustrează în detaliu unul din cele trei scenarii. 
Ca observații generale extrase din aplicarea metodelor subliniem faptul că cei trei pași - de la variații la studiul de caz - au forțat găsirea de justificări drept condiție pentru trecerea la o altă scară de detaliu. Totodată, astfel nu puteau fi săriți pași, în final toate proiectele rezultând în urma unei analize de la macro la micro.

Explorarea unor atitudini diferite, de la minimale la radicale/utopice, a putut scoate în evidență soluții care altfel puteau fi date deoparte, soluții de multe ori "out of the box". Prin analiza/punerea în balanță a unor soluții atât de diferite exercițiile de justificare au devenit complexe și au pus o presiune mai mare asupra studenților, forțându-i să studieze mai mult, să se documenteze etc.

\section{CURSURI ȘI SEMINARE}

Tematicile de la curs și seminar urmăresc de multe ori temele de atelier, completându-le sau chiar suprapunându-se. Studenții pot să-și aleagă seminarul urmat, legat de atelierul ales sau nu. Parte din profesorii de atelier îndrumă, de asemenea, seminare împreună cu profesori de la curs. 0 astfel de abordare asigură o uniformitate a informațiilor dar este totodată caracterizată printr-un grad de flexibilitate care lasă studentul să își formeze un mod propriu de abordare. Corelarea permanentă/dialogul permanent dintre profesorii care îndrumă aceste seminare și atelierele asigură, însă, succesul unui astfel de demers.

De exemplu, în cadrul Seminaire de la recherche critique adresat studenților de nivel Master 2, studenții pot opta pentru una din cele trei demersuri propuse de echipe diferite de profesori: 1. Architecture, écrits, 2. Analyse des proces. De concept 3. Patrimoine hérité.

La seminarul Architecture, ecrits textele produse reprezintă exerciții pentru disertație (scris academic, justificare prin trimitere la documentații, desprindere de concluzii, stabilirea scopului vs. relevanța pentru proiect etc.). Studenții își aleg subiectul pe care doresc să îl abordeze și își caută singuri documentația, apelând la diferite tipuri de resurse (cărți și articole fundamentale vs. recente - cu deprinderea justificării relevanței unui titlu pentru tema abordată, hărți, filme, website-uri, cercetări etc.). Se discută critic pe textele scrise de studenți, nu atât cu referire la temă, cât la modul de construire a demersului. Textul poate fi îmbunătățit pe parcursul seminarelor, lucrându-se pentru o singură lucrare predată la seminar per student.

Se pune accent pe două tipuri de piese ce vor fi predate: o panoramă și o viziune. Panorama cuprinde ilustrarea grafică a ideilor dezbătute în articol și a documentației consultate. Se urmărește plasarea în timp a ideilor, dezvoltarea, transformarea acestora 
prin prisma autorilor studiați, influențele teoretice de la un autor la altul, nuanțele teoretice, diferențele de viziune de-a lungul timpului etc., ilustrarea cercetării prin plasare pe două axe uneori. Rezultă o ilustrare a schimbărilor, intensificare a cercetărilor în domenii etc. ce antrenează capacitatea de ierarhizare și corelare prin înțelegerea în profunzime a autorilor studiați și ideilor acestora, privite critic și în raport cu alte lucrări, viziuni.

În cadrul cursurilor urmărite - Initiation à la recherche; Architecture, ville et territoire: théories et méthodes de l'urbanisme - partea teoretică s-a încheiat la începutul lunii decembrie, ultimele săptămâni din semestru fiind dedicate exercițiilor, discuțiilor, workshop-urilor etc. În cadrul acestor ultime săptămâni se desfășoară corecturi individuale și la panou. Astfel sunt aplicate cunoștințele teoretice dobândite indiferent dacă există sau nu seminare asociate. Studenții primesc în general teme-cadru, formulate drept teme de cercetare care fac necesară o documentare temeinică, sinteza informațiilor, analiza critică, elaborarea de diagrame și a unei viziuni. Prin lucrul pe un singur exercițiu care trece prin corecturi și revizuiri în urma feedback-urilor primite de la profesori și colegi deopotrivă se asigură obținerea unor rezultate mai bune și o mai bună înțelegere a rolului cursurilor respective în pregătirea profesională.

La nivelul Master 1, în programă este prevăzut cursul Initiation à la recherche care ilustrează, alături de cele de mai sus, deopotrivă importanța crescută acordată cercetării în proiectarea de arhitectură în mediul academic și rolul studierii și exersării unor demersuri care leagă teoria și practica prin cercetare. Cursul amintit urmărește cu precădere modul de construire a unui demers critic (de la documentare la ilustrare) inclusiv organizarea lucrului - și capacitatea de argumentare. Se stabilește o structură clară a materialului ce va fi predat, un anumit format, un anumit tip de piese (cât text, câte fotografii și cum să fie poziționate etc.). În paginile de text trebuie prinsă cheia proiectului în termeni de scop și metodă în timp ce imaginea-viziune ilustrează într-un mod arhitectural propria înțelegere și concluziile studenților față de subiectul abordat. Astfel se urmărește ilustrarea, într-un spațiu limitat (cel stabilit pentru predare), a unei serii de analize, procese logice, a demersului, sintezelor, concluziilor, până la ilustrarea unei viziuni personale care demonstrează înțelegerea subiectului și luarea unei atitudini (inclusiv asumarea acesteia). 


\section{CERCETARE}

Așa cum subliniam mai sus, cercetarea ocupă un loc major în cadrul tuturor activităților academice. Studenții consultă foarte multe surse, de diferite tipuri, citesc foarte mult (lucrări din diferite domenii), se informează cu simț de răspundere despre subiectul abordat și sit, cercetează abordări anterioare (proiecte realizate, proiecte studențești sau concursuri). Studenții beneficiază uneori, pe parcursul atelierelor, de prezența la corectură a unor cadre didactice invitate sau a unor cercetători ai universității care au studiat subiecte de interes pentru ei.

În marea majoritate a fișelor de prezentare a materiilor studiate sunt menționate abordările pluri- și interdisciplinare. La ateliere și seminare se face trimitere la studii din alte discipline, dar în final întotdeauna se caută viziunea arhitecturală asupra subiectului și inovația.

În cadrul masterului, temele de atelier și seminar sau temele de curs sunt toate tratate ca mici teme de cercetare, cuprinzând identificarea unor probleme reale, documentarea, sintetizarea informațiilor, extragerea de concluzii, rezolvarea arhitecturală. Abordările "out of the box" de la ateliere și seminare contribuie la găsirea de soluții inovatoare, la dezvoltarea creativității și la o mai bună pregătire pentru ceea ce înseamnă inclusiv activitatea de cercetare în arhitectură.

Aceeași coerență a abordării se identifică inclusiv în activități de cercetare propriu-zise, privite drept prelungiri ale activității academice în mediul real.

Metrolab Brussels (MLB) este un laborator transdisciplinar de cercetare urbană aplicată și critică. Este condus de UC Louvain în parteneriat cu Université libre de Bruxelles și colaborează cu instituții precum Bureau Bruxellois de la Planification, Bruxelles Environnement, CityDev, Innoviris. Metrolab are patru centre de cercetare, cel de arhitectură și urbanism desfășurându-și activitatea la UCLouvain-LOCl.

Metrolab este finanțat, pe perioada 2014-2020, de Regiunea Capitalei Bruxelles prin programul de finanțare ERDF (European Regional Development Fund). Centrul de cercetare are drept obiect de activitate proiectarea, implementarea și coordonarea unor proiecte de cercetare urbană ce țin de programul de finanțare ERDF-Bruxelles. La baza înființării centrului a stat dorința de a testa capacitatea cercetătorilor din mediul academic de a îmbunătăți un program de finanțare precum ERDF (aducerea mediului universitar și cunoștințelor din mediul academic mai aproape de actorii urbani cu scopul îmbunătățirii acțiunilor întreprinse de aceștia), dar și noi forme de implicare și relaționare în contextul cercetării urbane cu scopul îmbunătățirii calității științifice. Metrolab își asumă drept 
provocări principale (1) încurajarea actorilor urbani să întreprindă acțiuni cu un grad mai mare de reflexivitate și cu o privire critică, implicând, în același timp, cercetătorii într-un mod mult mai activ în cercetările întreprinse și (2) dezvoltarea unei teorii urbane mult mai bine conectate la siturile studiate și sensibilizarea unui public mai larg cu privire la problemele locale.

Proiectele dezvoltate în cadrul Metrolab (Fig. 2), publicate în volumul Designing urban inclusion (Berger et al., 2018), ilustrează cu succes atingerea scopului și obiectivelor. Acestea devin exemple demne de urmat în încercarea nu doar de a răspunde prin intervenții arhitecturale realității sociale, politice, economice, ci și de a avea un impact pozitiv asupra cât mai multor oameni, fără discriminare, depășind nevoi și cerințe primare, evidente.
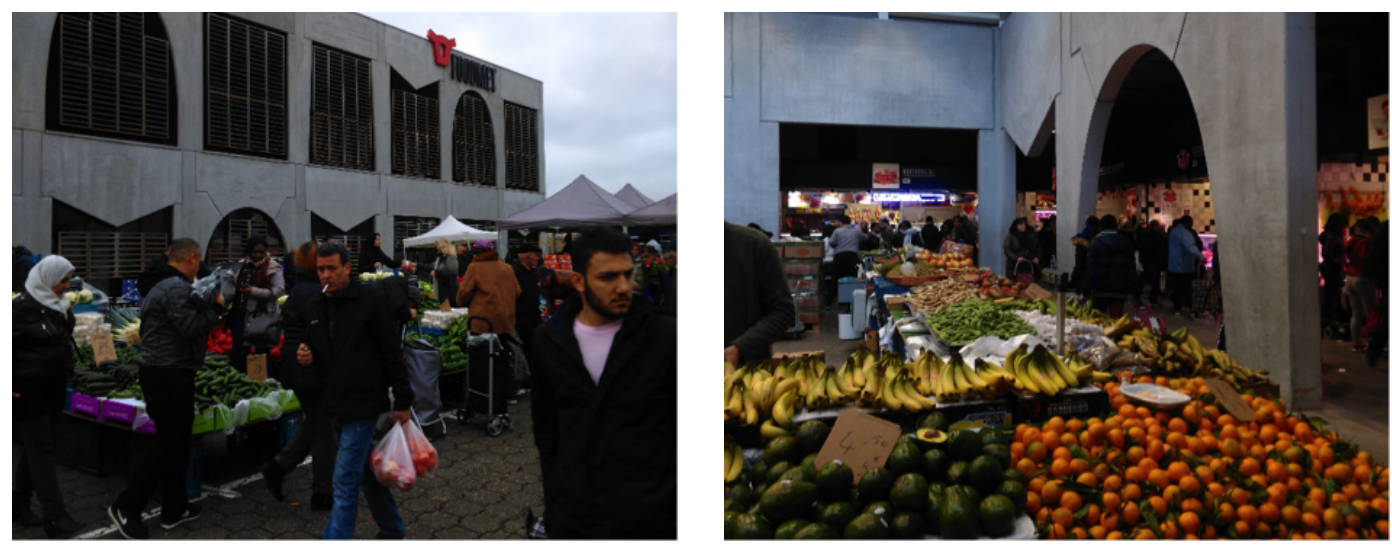

Fig. 2. Unul din siturile studiate de Metrolab - Abattoir, Anderlecht. Proiectul demonstrează posibilitățile dezvoltării unui proiect incluziv în jurul unui abator care în prezent se confruntă cu numeroase provocări generate de integrarea sa în intravilan, dată fiind dezvoltarea spațiului construit al comunei, dar și de schimbările sociale și economice.

\section{REZULTATE}

Atingerea rezultatelor așteptate, nu doar privind calitatea proiectelor predate, ci mai ales competențele acumulate de către studenți, stă în întreg procesul didactic și de cercetare. Discuțiile din cadrul corecturilor și corecturilor la panou de pe parcurs pun accent pe înțelegere și autoevaluare. De multe ori rămân expuse, pe toată durata atelierului/ seminarului, lucrările tuturor studenților, la final fiind discutate chiar comparativ abordările. Aceste discuții comparative reprezintă prilej pentru studenți de a înțelege de ce lucrările lor sunt evaluate altfel decât lucrările colegilor. Parte din prezentările de 
atelier și corecturi sunt chiar desfășu rate în afara cadrului universitar, astfel încurajânduse dialogul cu colegi din alte universități, cu alți profesori, cu practicanți sau chiar cu un public mai larg (de exemplu amintesc organizarea prezentării intermediare a proiectelor de către studenții UCL și KUL la CIVA Kanal).

Un element important în judecarea rezultatelor din punct de vedere al conținutului de informație și din punct de vedere grafic îl constituie pregătirea constantă a studenților în această privință. Numărul de planșe predate este de multe ori limitat (de exemplu, predarea de atelier de semestrul 1 de la master s-a făcut obligatoriu pe nu mai mult de 3-4 planșe 50/70). Astfel studenții fac inclusiv un exercițiu de selectare a informațiilor relevante, de exprimare a proiectului într-un număr limitat de planșe și piese. Este deopotrivă un exercițiu foarte bun de sinteză. Relevanța surselor consultate, pertinența concluziilor, calitatea propunerii, argumentarea sunt urmărite cu mai mare atenție în cadrul corecturilor de pe parcurs, ceea ce face ca prezentările finale să fie mai concentrate.

Modul de prezentare, paginarea, tipul de piese ce vor fi întocmite/predate sunt discutate încă din timpul atelierelor dar studenții par să cunoască deja foarte bine ceea ce se așteaptă de la ei în materie de reprezentare. Pot deja identifica singuri dacă proiectele lor sunt mai bine reprezentate prin secțiuni sau axonometrii etc. și unghiurile din care să realizeze axonometriile sau perspectivele pentru a-și face înțelese soluțiile. Secțiunile (prin clădiri, situri, profilurile stradale) sunt considerate piese esențiale. Denivelările sunt tratate cu mare grijă, în piese desenate și machete deopotrivă. Se lucrează foarte mult pe hărți. Sunt elaborate analize complexe. Se încurajează sintetizarea informației prin scheme.

Modul de prezentare a proiectelor este relativ unitar. Deși nu sunt obligați să respecte un anumit mod de reprezentare, ies în evidență câteva „reguli” ce par a da o anumită identitate a școlii în materie de reprezentare (număr de piese limitat, scheme, secțiuni axonometrice, axonometrii cu anturaj, prezentate alb/negru, în nuanțe de gri, cu griuri + una-două culori; colajele sunt singurele care uneori sunt prezentate color).

În ceea ce privește proiectele finale, întrucât temele abordate și proiectele în sine sunt diverse (intervențiile propuse fiind de la minimale la utopice), criteriile și exigențele de evaluare sunt flexibile într-o oarecare măsură. în principiu se urmărește caracterul inovator al problemei aduse în discuție și răspunsul arhitectural (coerența la nivelul țesutului urban, modul de rezolvare a unor probleme diverse prin intermediul arhitecturii). Analizele elaborate de către studenți demonstrează în general o foarte bună capacitate de analiză și sinteză. Totodată demonstrează capacitatea de justificare a ideilor, aceștia putând în general cu ușurință să explice mecanismele prin care au ajuns la anumite concluzii, la anumite scheme, să susțină o idee și să menționeze un scop. 


\section{OBSERVAȚII FINALE}

Observațiile prezentate mai sus rămân într-o mare măsură subiective, reprezentând citiri personale și o înțelegere trecută prin propriile filtre. Totodată, se limitează la proiectele, atelierele și seminarele urmărite, concluziile depinzând de temă, metode specifice aplicate, rezultate obținute. De exemplu, la alte proiecte decât la cel la care am asistat (la proiecte de semestrul 2, sau la proiectele dezvoltate urmând celelalte teme desprinse din tema-cadru) atitudinea se anunță a fi de altă factură. Urmărind celelalte proiecte concluziile este posibil să varieze, să sublinieze alt tipuri de atitudini, alte metode de cercetare etc. Totodată, urmărirea altor cursuri decât cele la care am putut participa (de exemplu cursurile de materiale, detaliere, echipamente) ar putea conduce la alte concluzii privind coerența sistemului în întregime și ar fi de urmărit pentru observarea legăturii dintre proiectul în curs și ceea ce se studiază în cadrul lor. Prin urmare, punând informațiile în perspectiva raportării acestora la obiectivele și strategiile didactice ale UAUIM, se pot formula o serie de reticențe legate de metodele aplicate și rezultate, dar acestea ar putea fi cu ușurință catalogate drept incorecte urmărind obiectivele didactice ale UCL-LOCI împărțite pe ani, semestre, teme. Voi menționa, însă, o serie de puncte tari pe care UAUIM le-ar putea avea în vedere în dezvoltarea/revizuirea propriilor strategii didactice:

- Împărțirea pe grupe pe baza exprimării de opțiuni de teme (teme diferite, din punct de vedere al programului sau modului de abordare etc.);

- Interacțiunea studenților din anii mai mici cu studenții din anii mari pentru a învăța unii de la ceilalți;

- Predările (ateliere, seminar etc.) drept exerciții de sinteză a informației și de exprimare a unei atitudini personale, critice atât prin desen, cât și text (respectând normele academice);

- Lucrările de seminar și cele de la finalul cursurilor - lucrări îndrumate pe parcurs, cu corecturi individuale și la panou. Temele lucrărilor - teme de cercetare, cu un conținut clar al predării care să acopere într-un mod sintetic nevoia documentării, analizei critice și reprezentării unei viziuni proprii asupra temei abordate;

- Utilitatea corelării cursurilor și seminarelor cu temele de la atelier într-un mod care ajută procesul didactic (obligând documentarea, sintetizarea informațiilor, reprezentarea);

- Introducerea de cursuri și seminare de cercetare; 
- Cursurile și seminarele desfășurate în ultimele două semestre - axate pe modul de construire a lucrării de diplomă și a disertației (exerciții complete de documentare, analiză, dezvoltare de propuneri etc.);

- Nevoia unui sistem coerent, aplicat încă din anul 1 de facultate, prin care studenții să fie învățați să colaboreze, astfel încât în anii 4-5 aceasta să fie o atitudine obișnuită. La UCL se identifică o coerență ce leagă: metoda didactică, teoria, atelierul, modul de reprezentare, finalitățile didactice, cercetarea, orașul.

\section{CONCLUZII}

Desfășurarea unui stagiu de o lună într-o altă universitate reprezintă o experiență importantă în vederea dezvoltării unor strategii și metode didactice ca urmare a observării unor alte metode, a modului de funcționare a unui alt sistem. Petrecerea unei luni, fără întrerupere, în aceeași facultate permite o observare foarte bună a aproape întregului demers, dar și corelarea informațiilor, revizuirea acestora prin punerea într-un context mai larg a întregului proces didactic ce cuprinde și cursuri, seminare. Pe parcursul unei astfel de perioade poate fi urmărit modul în care proiectele cresc de la o săptămână la alta, atitudinile profesorilor și studenților deopotrivă, pot fi înțelese altfel metodele utilizate, comentariile. Se pot decupa mai ușor ideile repetitive drept concepte de bază, se pot face legături între teme, materii, evenimente, oraș, istoria orașului etc. astfel încât concluziile extrase să fie de un real ajutor într-un proces de raportare la sistemul din care s-a plecat și de analizare a elementelor ce pot fi preluate, adaptate.

Înțelegerea orașului, a vieții urbane, urmărirea siturilor pe care se lucrează ajută deopotrivă în extragerea de concluzii și în punerea observațiilor într-o perspectivă mai largă.

Experiența stagiului a avut pentru mine, ca tânăr asistent, un rol major în formarea propriilor metode de lucru. Întâmplător, propriile mele viziuni și modul meu de a privi activitatea didactică anterior plecării și-au găsit corespondent în metodele observate în lucru la UC Louvain-LOCI, ceea ce m-a ajutat în conturarea unei direcții mai clare, mai bine structurate. Saltul făcut ca urmare a desfășurării acestui stagiu este într-o mare măsură vizibil în activitățile dezvoltate și coordonate ulterior (bazate, evident, și pe propriile mele preocupări):

- în prezentări susținute - în cadrul atelierului, în cadrul cursului de Teoria Proiectului - legate de experiența stagiului în sine, cu accent pe dimensiunea antropologică a cercetării de arhitectură, sau în prezentări organizate în parteneriat cu Departamentul de Informare și Documentare al UAUIM privind accesul la surse de informare relevante; 
- în seria de workshop-uri Text [re]presentation inițiate prin Departamentul Sinteza Proiectării de Arhitectură alături de conf. dr. arh. Magda Stănculescu (director de departament) ce urmărește realizarea de exerciții arhitecturale de citire critică, sinteză, reprezentare și prezentare de concluzii (până în prezent am organizat două astfel de workshop-uri);

- în propunerea de proiect de finanțare câștigat: SCHOLAR ARCHITECT - Perfecționarea și creșterea calității științifice în învățământul de arhitectură pe care îl coordonez (proiect finanțat prin CNFIS-FDI-2020-0655); proiectul are drept scop creșterea eficacității educaționale a UAUIM cu accent pe rezultatele învățării ca urmare a cercetării științifice specifice (fundamentarea proiectelor de arhitectură prin corelarea scrierii și cercetării științifice cu procesul de proiectare în mediul academic) și îmbunătățirea managementului calității prin accesarea resurselor adecvate predării, îndrumării, cercetării și învățării;

- în activitățile propuse prin proiectul mai sus menționat dintre care menționez programul de consiliere privind accesarea și scrierea de lucrări științifice care își propune „să faciliteze înțelegerea mecanismelor de publicare și concepere de texte științifice în domeniul arhitecturii prin oferirea de consiliere, în mod gratuit, membrilor UAUIM" (Scholar Architect, 2020).

\section{Referințe}

Berger, M., Moritz, B., Carlier, L., \& Ranzato, M. (Ed.). (2018). Designing Urban Inclusion. L.Capitan.

Scholar Architect. (2020, mai 26). Program de consiliere privind accesarea și scrierea de lucrări științifice. https://www.uauim.ro/evenimente/scholar-architect/ 